\title{
Implementation Strategies for Teaching And Learning Early Childhood In Education
}

\author{
Suid Saidi ${ }^{1}$ \\ ${ }^{1}$ Education Department Kutai Kartanegara University,Tenggarong \\ * Corresponding Author. E-mail: suid saidi2@gmail.com
}

Receive: 13/05/2021

Accepted: 23/08/2021

Published: 01/10/2021

\begin{abstract}
The goal of research Implementation of Teaching and Learning Strategies in Early Childhood Education is a Government program in an effort to improve the quality of human resources with the development of long-term investment through education activities as early as possible. Fundamentally, the Indonesian government has listed this program, as outlined in the Medium Term Strategic. Related to that, this research is aimed to see how far the effectiveness and efficiency of the process of implementing the activity specifically in the area of study. As an effort to improve the implementation of the form of activities of Early Childhood Education Implementation, the implementation process is carried out in order to obtain information as big as possible and high relevance, thus forming a focused discussion and sharpen the discussion undertaken. The problem of implementation of the strategy that runs systematically and projected is measured on the basis of the process of implementation and scope of activities in the implementation.
\end{abstract}

Keywords: implementation; learning; childhood; building; teaching

\section{Introduction}

Indonesia, consists of many ethnics, culture, language and beliefe principally become a part of the fundamental modal of Indonesia development nowadays and the future. From the democratic point of view, it is very important to socialize multicultural context earlier to the children and their family because children earlier education is not only individual achievement but also how people life together (Schleicher, 2012)To save the unit and unity of the state, so the process of understanding the meaning of multicultular context must be build earlier. However, to determine the quality of the activity of earlier children education generally or specially will be influenced by the condition of environtment, culture and tradition in every region. Therefore earlier children education should consider interaction between educator, teacher, mentor, nurse, and others to consider physicly, psychologically, learning curricullum that should be considered.(Mujito, 2014)
Implementation of teaching and learning strategy in the earlier children education principally supported by some important factor as shaping of executing process as long as it is fixed with the purpose and the target that will be aimed. The UN statement said that only a few support of earlier children education pattern has significance caused toward poverty nowadays. It is not surprising that there are 20 $\%$ disable people belongs to the most poverty people in the world with the level of educated people only $3 \%$ and jobless almost $80 \%$ (Hartnett-Edwards, 2007)

This problem become a fundamental refference for all component and the part especially in the term of education to help defining a step and executing process and clear aplication with technique mechanism which will be applied in the implementation of early childhood education learning strategies. The component that must be seen in implementing of early childhood education strategies in Indonesia especially in the region of studies, sistematically is needed process of cultural 
approach and local wisdom development. Close to that case the great investation of understanding in the society has not fully understood that earlier children education is a basic of development in the future,(Taufik Apendi, \&Saidi, 2019)

Basiccally, building understanding about the importance of earlier children education process must be built as long as the implementation of teaching and learning education applied. Mechanically, it should be built an understanding that the process of application of early childhood education activity will definite the level of quality of life the future generation( Prastiwi,Iham\&Elihami,2020) Application process that is applied must be evaluated accyrately in defining how far the effectivity and efficiency application pattern that is applied can be accepted and understood by all the society level.(Yanuarti, 2018)

An obstacle that happened in the field show that the process of earlier children education activity application is still only applied for a group of people that has a high economy evel, whereas the right of human education is for a long life. Because of that case therefore it needs a fixing of implementation system strategy in earlier childreen education application in which in that age it is still possible individual productivity can be developed throughout early childhood education (Faizah, 2016)The change in the future is determined by the result of process of

earlier children education application nowadays and can be predicted for the future as the basic and purpose that is fixed(Eynon \& Helsper, 2015)

Investation is a componen that will be gained for a long time. As a supporting factor the succeed of investation activity supported with good and qualified human resources. The human resources itself needs to be shaped since the early childhood. The implementation of teaching and learning strategy in the earlier children education is really needed, because of condition, (Padmowihardjo, 2014)situation and global development that is always developed. The research result that is consistent in this year in many countries can be conclude the substantial of positive effect of earlier children education has been found by shaping cognitif development, succeed and school gaining, healthy and social behaviour (Saidi.S, 2019)

Implementation of the established strategy must be appropriate with the balance of conditions, situation, family, environment, patterns, processes and mechanisms and systematic implemented. In relation to the community groups in Indonesia generally and especially in the study area then the application of techniques is specifically needed in setting of the strategy step as the implementation of learning and teaching in early childhood education.

Considerated by looking at Piata's statement and colleagues regarding the process of early childhood education activities, Although there is an increase in relation to the value of public investment in Early Childhood Education in general, there is no agreement on the most effective programs and policies, and about the things that are important to quality (Rahman, 2009) From the statement it is concluded that the strategy of the process of implementation of the whole standard is difficult to be determined considering the age of development of early childhood from 3-5 years old is still in the formation of both cognitive, affective and psiomotorik still in process. In addition, environmental, daily, habitual and cultural factors and beliefs are the main factors of pure formation that affect the stability of the talent and kemempuan attitudes that are owned, it will be different in each place where the level of environmental and situational difficulties both socially and economically will distinguish naturally from the basic development of early childhood.

Within the scope of this study, the pattern of balanced implementation which is the implementation of teaching and learning strategy in early childhood education must be balanced. Opening the opportunity of all the ranks and classes of society at large where the development of early childhood education is not entirely must with high economic value and investment. Evidence of the Extent of Early Childhood Education Evidence of the positive effects of Early Childhood Education quality is consistent throughout the world, taking into consideration that the quality of Early Childhood 
Education should be stated based on conditions at home(Frierson, 2015) . Implementation of the strategy requires the process of Early Childhood Education implemented in an effort to improve self regulation, motivation, selfefficiency, educational aspirations, hospitality and aggressive or anti-social behavior. Review research on education and support programs for parents of early childhood education centered in low-income countries, concluding that both have a significant impact on children's cognitive and social-emotional development .

Principally, the components of the implementation of the development of thinking, attitudes, behavior and ability of early childhood can be directed in accordance with the needs and achievements to be determined in the future. Implementation of the strategies applied in the learning and teaching process should involve all aspects of multicomponent in the scope of family, environment, centered and so on supported by caregivers, mentors, reliable education and character building based on culture, local wisdom, environment and berbangsan and state the future. This case is proven in high-income countries, research has found positive long-term effects including increased cognitive ability, educational achievement, and adult income

\section{Methods}

\section{Participants and Research Design}

The character that is able to improve the management of the quality of learning and is part of the culture in improving the performance and quality of learning in schools of kinder garten which is a phenomenon in life. Many things that can call attention when entering the area or environment of the research subject, because of the variety of physical and non-physical aspects of the agency that are indirectly highlighted for public attention(Vagle, 2016).

Without guidance in making observations, it will take too long to obtain data and information that is substantially needed in research. For this reason, the observation guidelines are compiled so that the data collection is truly directed, focused and selective, (Milles et al., 2014) systemik observations are made based on the problem to be explored and observing the goals that represent the problem

There are three main problems in this study. In this study the authors conducted a study of five school leaders as participants and also became an important step, to explore information, observations, interviews and documentation, comprehensively, the time of the study was about 4 months ( 16 weeks), and the location of the study in five kinder garten/PAUD schools, in the research object. Conducting interviews refers to structured designs in the form of a list of questions that are used as core guidelines. For the depth of data and information, questions can be further developed to find important points that support the ful fillment of research data needs

Not all questions on the list are emphasized equally in each data source, although it is offered to all data sources, but the weight is distinguished by considering the position and capacity of representative data sources for the institutions they represent. Interviews are open, carried out by observing manners of communication to the intellectual community, respecting data sources as valuable partners and paying attention to ethical standards in research

This research is a deepening of the character, psychological of a person, so the author sees that the research must be conducted with a qualitative perspective approach and a phenomenological model, as , according from, I question my own cultural competence as a teacher and principal. Changing reflective views on my life experience as an educator creates a space where I try to make meaning from the phenomenon of culturally relevant practices in education, then opinions from a qualitative, as "a process of understanding inquiry based on the tradition of different inquiry methodologies that explore social or human problems" (Creswell, 2013)

Phenomenologycal Qualitative Research Design,the problem of early childhood is a social problem and is a phenomenon that often occurs in daily life ,according from (Moustakas, 
2011)Phenomenology / phenomenon is a philosophical expression and also a model approach in qualitative research. Basically, phenomenology deals with understanding of how every day.

world, behavior is inter-subjective or also the real world (reality) In addition to conducting interviews the author also gave a limited questionnaire (purposive sampling) to five participants, this questionnaire was to ask participants to answer questions in writing, so that (King, 2007)

the analysis of the data that the author received received two answers both written and oral, and conducted in-depth interviews with participants

In qualitative research using a questionnaire is not to look for populations as in quantitative research, but in qualitative research the use of a limited questionnaire is to explore more specific information for participants, who are considered to meet the criteria as informants.(Applebaum, 2016)

\section{Analysis Data Phenomenologycal Qualitative Research Design}

Uses data collection techniques and data analysis, using the IPA (Int erpretative Phenomenological Analysis) model, from (Smith \& Osborn, 2008) Stages, (a). Read and re read (b). Initial notes (c). Developing Emergent themes; (d) Look for connections in all themes that appear; (E). Move the next case; (f). Look for patterns in all cases. The author validates the data by processing it in accordance with qualitative research procedures, by deepening the analysis of the data obtained, and processing the interview data.

Broadly speaking, data collection is done through interviews and field observations, also strengthened by a review of relevant documents. Interviews were conducted in the form of individual conversations, as well as groups (in the form of discussions) both informal and formal with regard to data sources.

While obervasi or direct and attached observations are done by involving themselves in work situations that occur in the research subject environment. The document review is conducted on written data and information available from data sources and from third parties who have relevant information or are related to the research topic. For each of these purposes, a kind of guideline was prepared which was used as a guide for researchers in the field. Throught the accuracy and reliability of the data and verification of data analysis, and from the results of the analysis process produces five phases (stages) in selecting prospective leaders in the institution or at school.

\section{Result and Discussion}

Early Childhood Education is a national government program with an orientation to prepare the next generation of the nation of Kutai regency projected this education process seriously. This matter is poured in the form of determination of early childhood education goal which stipulated by The main objective: to establish a quality Indonesian children, the child who grows and develops in accordance with the level of development so as to have an optimal readiness in entering basic education and navigating life in adulthood. Purpose of the

Participant: to help prepare the child to achieve the readiness of learning (academic) in school.Regency Government of Kutai Kartanegara as follows:

Early childhood education (PAUD) is the level of education before the education level. The basis of which is a coaching effort aimed at the child from birth up to the age of six through the provision of educational stimuli to assist physical and spiritual growth and development in order for the child to have readiness in entering further education, organized on formal, nonformal, and informal. The calculation to obtain early childhood education data can be obtained from the publication data of Kutai Kartanegara Money Arrangement Institution Achievement of PAUD in Kutai Kartanegara Regency in $50.97 \%$ and then it increased to $52.99 \%$ and $73.06 \%$ APK Paud decreased to $46.95 \%$. The value again rose to $76.80 \%$ in 2014-2018 and again down in to 53.51\%. The picture below shows inconsistency to the achievement of PAUD in Kabupaten Kutai 
Kartanegara for every year which should be the attention of the Government of Kutai Kartanegara Regency. (Covell et al., 2009)The achievement of indicators of early childhood programs is still very low, this is probably due to the low awareness of the community about the importance of early childhood education. In addition, the distribution and implementation process of early childhood education activities is still sectoral and not yet thoroughly rooted to the smallest environmental environment in the community. Lack of factors of technical executive staff both educators, mentors, builders and other implementers is still very poor so that the expected achievements have not been maximally can be implemented

From the basic components of field data information has been confirmed. That the needs of infrastructure facilities, support executors, the establishment of systems and processes are still in basic formation. In a system of sectoral implementation processes precisely the process of implementing these activities only revolves around a certain environmental environment with a level of understanding and economic and social mature. Not yet touching to the basic orientation of the implementation of early childhood education(Keeney, 2019) activities thoroughly.Actually the components can actually be developed with the implementation of a simple strategy. Where the family environment becomes the basis of a definite education with carefully optimized directives in this understanding of the component environmentally developed with the development (Yu \& Prince, 2016)of environmental optimization as a strategy of learning and teaching the process of early childhood education.

In component with the basic principles of human resource development for the future, the interpretation generated from the conditions in the study area is required of active cooperation of all components that have the policy of the Local Government, the relevant Office and Society to realize the process of early childhood education in the implementation of strategy effective, efficient and effective teaching learning in accordance with generally defined process provisions without prejudice to cultural values, local wisdom and the environment. With diversity is expected to be a potential for the development and development of a more advanced forward.

On the basis of the results of ethnographic studies (Nixon, 2015) clearly show that parents are substantially different in the meaning of Early Childhood Education and on what represents good practice regarding decency, home in Provisions, penalties and other educational issues, as well as on what parent participation means (Reid, 2019)Principally, the implementation process of the teaching and learning strategy in early childhood education is still dominated by $60 \%$ by families with basic family ethics, $25 \%$ of the environment with the community and adaptive condition situation with the needs of the early childhood. And $15 \%$ support counselors, caregivers, educators in aligning process components systematically as the basis for achieving the goals set by the government in building human resources early on(Bell, 2017).

It is important to be understood that there are many possible points of view about quality (Korkmaz et al., 2017)), and the parent perspective may differ from professional understanding. It is not appropriate to arrange accessible and affordable Early Childhood Education; The service also needs to be desirable and useful from the point of view of parents (Shlay, Tran, Weinraub and Harmon, 2005). From the description it is stated that differences in viewpoint about early childhood education in the community have not fully understood the importance of the process in developing human resources in future. Economic thinking becomes the basis of the process is not required then the implementation of strategy needs to be applied carefully and precise system mechanisms without reducing the value of early childhood education process malalui guidance and direction of the educators provided by the government and other implementing techniques. This is in line with the expression of Sameroff tang declared a comprehensive, well-designed and inclusive resonance system that resonates well with a capability approach. They conceptualize all children as active and capable beings, proactively building their understanding of the world since the early stages of life (Tatang Apendi\&Suid Saidi, 2020) 
The second important factor of contextual factors is the influence of culture, including the traditions of values and intergenerational parenting patterns. The attitudes and beliefs about parenting, children's and parent-child relationships are often culturally informed. For example, Lansford and colleagues (HartnettEdwards, 2007), Indonsesia with diverse cultures and languages and tribes in great need of attention in building relationships and cooperation in the social sphere. Therefore, the process of implementation of teaching and learning strategy is expanded with the development of attitude in the environment directly to build the thinking and expansion of cognitive abilities and early childhood affective. This in principle will build the components of equalization, togetherness and unity in the environment to keep each other's relationship from the beginning of the thinking of human development goes.

In the implementation of learning strategy implementation teaching in early childhood, the programming that focuses on attachment to achievement is very important in the first few months of learning as a step to evaluate early childhood attitudes, talents and abilities. In situations where they are focused on the position of continuing school entry into the Priority programs to primary school. There is also a need to determine effective mechanisms for reaching different types of programs and Results eg Are individual programs better than group-based programs to achieve decreased violence against children? Third, the characteristics, skills and training of effective service providers still have to be determined. Therefore, while we have a number of effectiveness trials, further investigation is needed to determine the mechanism of deliverable programs that can be implemented on a scale of certain scale.Identify the right entry point Review programs to define strategies to demonstrate that they are supported and implemented preferably under government, non-governmental and intergovernmental support for lucrative sectors. Support of other programs can be established with the support of the health sector, in addition to education and others.

The involvement of several sectors is expected to provide a space for understanding and understanding of parents as the main path to reach children who will be educated in the process of teaching and learning in early childhood education. However, this multisectoral approach is also a challenge since it is very rare to implement cross-sector coordinated programs that lead to the identification of appropriate entry points to introduce important programs with the aim of providing services to the family in a coordinated manner. Future work should focus on identifying entry points that allow a coordinated approach. Extending the focus to include families It has been speculated that parenting is an academic term for representing reality, that is family. The shift of a suggested approach from parenting to the family may be useful in enhancing the impact of intervention. This recommendation does not only come from the definition of parental migration due to changes in health, demographic and economic demands in the community, but also recognize that the immediate context of youth is made up of several key individuals who are family. Also, 'family' as an institution. Acknowledged across sectors, and especially in times of conflict and disaster, is often the only institution who can support the child. Principally, parents create contexts in which children grow, develop, learn and develop (Riana, 2008) Implementation Effective learning strategy in early childhood effective efficient does not put forward the economic value but precise and careful guidance and direction process through guidance to family and society environment will be more effective and efficient in developing attitude with development and understanding in its own environment.(Ali, 2020)

The excellent potential viewed based on the diversity as the above theory has been mentioned Indonesia in general and in particular the study area is a region with quite a variety of ethnic groups both indigenous and migrant tribes. From these things, environmentally this component has provided learning as the basic capital of early childhood education in the development of thinking and attitude in social interaction well. In addition, the carrying capacity of the environment itself can be optimasliasi be the object of environmental education object with the understanding of the scope of thought balance and the utilization of 
the environment in a fundamental way. Multisectoral relationship development can be built by establishing active cooperation with the intensive and in-service ranks in the effort of socialization in the process of implementation of teaching and learning strategy in early child with effective efesein and economical.

Problems and weaknesses, in the implementing components of supervising techniques, coaches and educators in the environment of early childhood education activities are lacking. Problems and weaknesses have not yet its special regulation governing the process of community-scale education development and supported by a clear policy from the government. For the community level, the process of early childhood education is still sectoral for the established economy group supported by a broad understanding. Characteristics of local and regional communities do not fully understand the components of the process of implementing early childhood education activities for the advancement of the environment, the nation and the country in the future.

Future Trends and Charges, the trend of education will continue to increase as well as the uneven distribution rate. This needs attention to the process of placement and development of early childhood education sectors in the community. Arrangement of location and development center of children activity center, as well as cadre and guidance of caregiver and supervisor of teaching learning process implementation process for early childhood education.

Future demands with the opening of the global market will require reliable and qualified human resources, early formation support is needed in an effort to improve thinking and understanding of the environment and utilize it in everyday life. Establish active cooperation and create high cultural values as a definite capital base of development.

Anticipatory Steps and Improvement Efforts in the implementation of teaching and learning strategies in early childhood in anticipatory steps is needed broad socialization and human resource development of managers and implementing techniques in the scope of early childhood technical education activities. As for the improvement effort, it is built the understanding of simple and easy operational scope by cooperating with all parties in realizing the form of continuous early childhood education process. Develop all potentials with all forms of process in building early childhood thinking, attitudes and skills carefully and precisely.

\section{Conclusion}

In the implementation of early childhood education process in the implementation of learning and teaching strategies not only involves the pattern of sectoral system well developed by the government through the form of early childhood coaching is implemented. The development of long-term quality and quality of human resources needs the support and understanding of all parties.Both the government, institutional and social. Implementation of teaching and learning strategies through the formation of parenting patterns, components of the proportion of activities developed more widely by involving factors family, environment and condition of the existing situation. Introduction tesebut the strategy more directed to the establishment of moral value, culture and value system in the determination of attitudes and pembentuka personality. Other things of communication and community relationships are built with the scope of the learning process. It is advisable that early childhood education activities should be implemented $60 \%$ in each learner's environment and developed active communication. It is not implemented with sectoral systems and academically prescribed education. However, the process of education is more optimized to the development and understanding of active cultural mental, creative togetherness and help each other from an early age so that will be embedded until later.

\section{References}

1 .Ali, T. (2020). ANALISIS INDIKATOR KEGAGALAN SISWA DALAM MENEMPUH PENDIDIKAN DI SEKOLAH. Jurnal IImiah Pendidikan Dan Pembelajaran(JIPP), Vol 4, No, 537-545. https://doi.org/DOI: http://dx.doi.org/10.23887/jipp.v4i3.2398 9 
2.Applebaum, M. (2016). Phenomenological psychological research as science. In Journal of Phenomenological Psychology. https://doi.org/10.1163/156916212X6329 52

3.Bell, L. (2017). Research Methods for Social Workers. In Research Methods for Social Workers. https://doi.org/10.1057/978-1137-44283-3

4.Covell, K., McNeil, J. K., \& Howe, R. B. (2009). Reducing teacher burnout by increasing student engagement: A children's rights approach. School Psychology International. https://doi.org/10.1177/01430343091064 96

5.Creswell, J. (2013). Qualitative, quantitative, and mixed methods approaches. In Research design.

6.Eynon, R., \& Helsper, E. (2015). Family dynamics and Internet use in Britain: What role do children play in adults' engagement with the Internet? Information Communication and Society. https://doi.org/10.1080/1369118X.2014.9 42344

7.Faizah, A. M. (2016). Kajian Tindakan dan Pembangunan Profesional Guru-guru di Malaysia: Cabaran dan strategi. Seminar Pendidikan.

8.Frierson, P. R. (2015). Maria montessori's philosophy of experimental psychology. HOPOS. https://doi.org/10.1086/682395

9. Hartnett-Edwards, K. (2007). The social psychology and physiology of reading/language arts achievement. In Dissertation Abstracts International Section A: Humanities and Social Sciences.

10.Keeney, A. J. (2019). School social workers' perceptions of ethical dilemmas associated with electronic media use in school settings. Children and Schools. https://doi.org/10.1093/cs/cdz019

11.King, N. (2007). Phenomenological Psychology: Theory, Research and Method. In Qualitative Research in Organizations and Management: An International Journal. https://doi.org/10.1108/17465640710778 548

12.Korkmaz, H., Thomas, J. A., Tatar, N., \& Aktas Altunay, S. (2017). Students' Opinions about Science and Technology in Turkey and the United States: A Cross-Cultural Study. International Online Journal of Education and Teaching(IOJET). http://iojet.org/index.php/IOJET/article/vi ew/211/175

13. Milles, M. B., Huberman, M. A., \& Saldana, J. (2014). Qualitative Data Analysis A methods Sourcebook Edition 3. In Sage Publications, Inc.

14.Moustakas, C. (2011). Phenomenological research methods. In Phenomenological research methods. https://doi.org/10.4135/9781412995658

15.Mujito, W. E. (2014). Konsep belajar menurut ki hadjar dewantara dan relevansinya dengan pendidikan agama islam. Pendidikan Agama Islam.

16. Nixon, J. (2015). Learning to think together. Teaching in Higher Education. https://doi.org/10.1080/13562517.2015.1 022057

17.Prastiwi,Ilham\&Elhami (2020) Developing Creative Thinking and Physics Students' Achievement by $u$ sing CPS,EDUMASPUL:Jurnal Pendidikan pp.3033. https://ummaspul.ejournal.id/maspuljr/article/view/684

22.Padmowihardjo, S. (2014). Psikologi Belajar Mengajar. Pengertian Psikologi Belajar Mengajar Dan Definisi Proses Belajar.

23.Rahman, U. (2009). KARAKTERISTIK PERKEMBANGAN ANAK USIA DINI.

Lentera Pendidikan : Jurnal IImu Tarbiyah Dan Keguruan. https://doi.org/10.24252/Ip.2009v12n1a4

24.Reid, D. B. (2019). What information do principals consider when evaluating teachers? School Leadership and Management. https://doi.org/10.1080/13632434.2019.1 576167

25.Riana, C. (2008). Media pembelajaran: hakikat, pengembangan, pemanfaatan, dan penilaian. Wacana Prima, 5-35. https://books.google.co.id/books?id=ku0_ DwAAQBAJ\&printsec $=$ frontcover $\&$ source $=$ gbs_ge_summary_r\&cad=0\#v=onepage \&q $\& f=f a l s e$

26.Saidi.S, A. tatang T. (2019). Analysis the Hidden Advantages of Written Pretests for Student Intelligence. International Journal for Educational and Vocational Studies, 
1(7), 15.

https://doi.org/10.29103/ijevs.v1i7.1677

27.Schleicher, A. (2012). Preparing Teachers and Developing School Leaders for the 21st Century: Lessons from Around the World. In OECD Education and Skills. https://doi.org/10.1787/9789264174559en

28.Smith, J. A., \& Osborn, M. (2008). Interpretative Phenomenological Analysis. In Doing Social Psychology Research. https://doi.org/10.1002/9780470776278.c h10

18.Tatang Apendi, Suid Saidi, A. T. (2020). LEARNING ENTREPRENEURSHIP FOR STUDENTS IN PREPARATION FOR JOB OPPORTUNITIES. International Online Journal of Education and Teaching (IOJET, 7(7), 499-507. https://iojet.org/index.php/IOJET/article/vi ew/853

19.Taufik, Ali, Tatang Apendi, Suid Saidi, and Z. I. (2019). Parental Perspectives on the Excellence of Computer Learning Media in Early Childhood Education. 13(November), 356-370. https://doi.org/DOI: https://doi.org/10.21009/JPUD.132.11

20.Vagle, M. D. (2016). Crafting Phenomenological Research. In Crafting
Phenomenological Research. https://doi.org/10.4324/9781315431451 21.Yanuarti, E. (2018). PEMIKIRAN PENDIDIKAN KI. HAJAR DEWANTARA DAN RELEVANSINYA DENGAN KURIKULUM 13. JURNAL PENELITIAN. https://doi.org/10.21043/jupe.v11i2.3489 29.Yu, C., \& Prince, D. L. (2016). Aspiring School Administrators' Perceived Ability to Meet Technology Standards and Technological Needs for Professional Development. Journal of Research on Technology in Education. https://doi.org/10.1080/15391523.2016.1 215168

\section{Profil Penulis}

Profil singkat berupa narasi data kelahiran; pendidikan dari jenjang sarjana sampai pendidikan terakhir yang berisi prodi, dan tahun kelulusan serta pekerjaan/aktivitas yang dilakukan sampai saat ini. 